\title{
The levels of disclosure relating to mine closure obligations by platinum mining companies
}

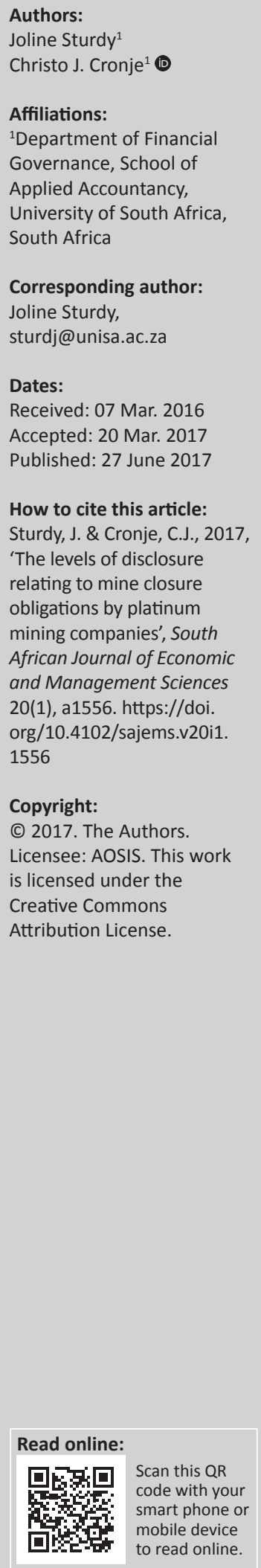

Background: Mine closure obligations are economically significant, and the consequences of insufficient mine closure obligations are of public interest. The incidence of acid mine drainage and the high number of ownerless and abandoned mines in South Africa have brought the consequences of insufficient mine closure obligations in the mining sector into the spotlight.

Aim: The aim of this study is to establish the extent to which platinum mines listed on the Johannesburg Stock Exchange (JSE) comply with a recommended disclosure framework.

Setting: South Africa is the largest producer of platinum in the world. The study covers all platinum mines listed on the JSE.

Methods: Using a framework, a census of the annual financial statements, integrated annual reports and sustainability reports or websites was conducted to determine the level of compliance of disclosure relating to mine closure obligations to the recommended disclosure framework.

Results: The results show disclosure relating to mine closure obligations of platinum mines listed on the JSE is inconsistent and not sufficient for stakeholders to understand the scope, key assumptions, parameters or reliability of the assessment and calculation of mine closure obligations.

Conclusion: The assumptions used to determine mine closure obligations are specialised and multi-disciplinary. The accuracy and reliability of mine closure obligations will improve dramatically through greater transparency and access to information. It is recommended that the JSE listings for mining companies should require a competent person's report to provide disclosure on assumptions, key values and processes applied to determine the mine closure obligations. Furthermore, it is recommended that the Department of Mineral Resources implements a mechanism of independent assessment of mine closure obligations by experts on an ongoing basis.

\section{Introduction}

There is an enormous body of research relating to corporate social responsible reporting and the reasons why companies disclose social and environmental information. Companies are reluctant to inform the public of environmental and macroeconomic risks their business activities could cause (Yoo \& Nam 2015). Companies with a good image and reputation tend to disclose more environmental information (Zeng, Xu, Yin \& Tam 2011). Roberts' (1992) study confirms that the levels of corporate social responsible reporting are significantly influenced by stakeholder power, strategic posture and economic performance. Corporate financial profitability is a key factor that influences corporate social responsible reporting, but Khlif, Hussainey and Achek (2015) found that national culture moderates the association between profitability and corporate social responsible reporting. De Villiers and Alexander (2014) found evidence that management intent or company social and environmental performances do not necessarily drive corporate social responsible reporting but is rather a reflection of global corporate social responsible reporting templates. It is also well known in literature that company size and industry influence the level of corporate social responsible reporting. However, De Villiers, Low and Samkin (2014) found specifically that the field of corporate environmental disclosures among mining companies only listed on the Johannesburg Stock Exchange (JSE) reached a level of maturity and professionalisation causing environmental disclosures by small companies to become similar to the disclosures by large companies.

There is a disparity in the amount of information presented in the corporate annual reports of mining companies with respect to mine closure obligations (Deloitte 2007; WWF 2012). Mine closure 
obligations include the provisions for decommissioning and rehabilitation. The estimation uncertainty of mine closure obligations creates an opportunity where management can plausibly withhold 'bad news' (Deegan \& Rankin 1996; Ferguson \& Walker 2011). This situation allows management to either withhold disclosure of 'bad news' to protect their proprietary information for economic advantage (Dye 1985) or presents an opportunity to reduce the price impact on the per share value of a company by either disclosing or withholding information (Verrecchia 1983). Tilt and Symes (1999) argue that income tax incentives relating to mine rehabilitation present an alternative explanation for disclosures relating to mining rehabilitation in Australian mining companies. Investors interpret the disclosure of mine closure obligations as a positive sign of the company's ability to manage their exposure to future costs (Ferguson \& Walker 2011).

The incidence of acid mine drainage and the high number of ownerless and abandoned mines in South Africa have effectively brought the consequences of insufficient rehabilitation provisions in the mining sector into the spotlight (WWF 2012). Section 41 of the Mineral and Petroleum Resources Development Act 28 of 2002 (MPRDA) is based on the 'polluter pays' principle (Republic of South Africa 2002). During 2009, the Auditor-General estimated that the cost to rehabilitate 5906 abandoned mines will be at least R30 billion (Auditor-General South Africa 2009). It is clearly in the public interest that the level of disclosure relating to the provisions for decommissioning and rehabilitation be improved to ensure public scrutiny of the calculation of mine closure obligations.

This study found that even with the introduction of the International Integrated Reporting Framework and the Global Reporting Initiative (GRI) guidelines, crucial areas remain where mining companies fail to be transparent. There is evidence that the type of information in respect of mine closure obligations disclosed by companies listed under the platinum and precious metal sub-sector on the JSE is varied and reveals little about the company's estimations used to determine the mine closure obligations. The implications are that public scrutiny of the calculation of mine closure obligations is limited, and mining companies in South Africa should engage stakeholders to determine the information they need to disclose relating to mine closure obligations.

Mine closure obligations are economically significant in the mining sector. Various macro and sub-macro factors influence the recognition of appropriate mine closure obligations and transparent reporting of them. This leads to the research question of this study.

\section{Research question and objective}

The research question is as follows: To what extent do platinum mines listed on the JSE Limited comply with a recommended disclosure framework regarding their corporate social responsibility in respect of mine closure obligations?
The objective of this study is to establish the extent to which platinum mines listed on the JSE comply with this recommended disclosure framework.

The rest of this article is organised as follows: firstly, an outline of the various drivers determining the levels of provisions for decommissioning and rehabilitation is given, followed by a discussion of the theoretical perspectives of this study, then a description of the sample selection and research methods are provided. A presentation of the results follows, and finally, the conclusion and recommendations are presented.

\section{Background and literature review}

Although a review of the relevant literature provides insight into environmental disclosure, decisions or factors driving the level of disclosure can be complex and are still not fully understood (Summerhays \& de Villiers 2012). Various factors drive the level of decommissioning and rehabilitation provisions reported in corporate annual reports as well as in corporate sustainability reports. These factors can generally be described as macro and sub-macro factors (Deloitte 2007).

\section{Macro drivers}

Group-specific and regional factors drive the level of disclosure of provisions for decommissioning and rehabilitation. These drivers include the company's portfolio of mines, the accounting and financial reporting framework used to govern accounting practices and specific group policy relating to rehabilitation of the company's mines.

The portfolio of a company's mining operations may include various mines in different stages of the mining process. Environmental impact starts when mining commences and deteriorates rapidly when mine closure is reached (Van Eeden, Liefferink \& Durand 2009). Mining companies can hold mining licences over large areas of land, but the environmental impact of mining activities can be better assessed against the amount of land already disturbed and by the amount of land already rehabilitated (GRI 2013). The status and mix of operational and closed mines of a mining company will influence the monetary balance of the mine closure obligations in the statement of financial position and the related disclosures (Deloitte 2007).

Decommissioning and rehabilitation provisions are covered under IAS 37, Provisions, Contingent Liabilities and Contingent Assets (IASB 2014). As mining operations disturb the environment, a significant part of a mining company's legal or constructive obligation to rehabilitate the environment arises during the construction phase, with the provision growing as the operations increase (Ferguson \& Walker 2011). From a disclosure point of view, IAS 37 requires a reconciliation of movements for each class of provision. The accounting standard against which mining companies report their mine closure obligations will influence the level of disclosure. 
Mining companies have a visible impact on the environment and therefore come under close scrutiny from environmental groups and concerned citizens (De Villiers \& Barnard 2000). Mining companies have potentially complex relationships with the environment which indirectly influences the relationship between the affected communities and the natural environment (GRI 2013). Some companies go beyond the minimum requirements of local legislation and develop common standards across a group of companies in determining expectations and obligations to address the socio-economic impacts of mine closure (Deloitte 2007). An example of a group policy is the 'Closure Standard' Rio Tinto adopted, which requires that business decisions must take into account closure considerations from the earliest stages of project development, bearing in mind that stakeholder consultation is a vital element in closure planning (Rio Tinto 2012). Environmental disclosure policies are difficult to define because the disclosed information is often unrelated to a company's performance (Magness 2006). But, understanding the definitions and applications of group policy to mine closure obligations and how these relate to determining forecast expenditure is important to assess a company's mine closure obligations (Deloitte 2007). Therefore, group policy and biodiversity strategies will influence the level of disclosure of mine closure obligations.

\section{Sub-macro drivers}

Sub-macro-level drivers refer to country and mine-specific factors influencing the level of disclosure (Deloitte 2007). These drivers include the characteristics and environment of the mines and country-specific mine closure legislation.

The scope and nature of closure activities depend on the ore body characteristics and the environmental setting of the mining operations (Deloitte 2007). The characteristics of the ore body will influence the types of mine, which are either open cut or underground. The type of mine influences the type of rehabilitation activities. Mining operations impact on biodiversity in various ways and to a degree depend on the location and sensitivity of the area (GRI 2013). Mining operations situated in environmentally sensitive areas are likely to have higher costs relating to rehabilitation of the environment (Deloitte 2007). The level of rehabilitation required by regulatory bodies has gradually increased in recent years (Ferguson \& Walker 2011). Therefore, the age, location and type of mine influence the monetary balance of the mine closure obligations and the related disclosures.

The level of environmental disclosure is furthermore influenced by the enforcement efforts of regulatory bodies (Neu, Warsame \& Pedwell 1998). South Africa has various legislative frameworks for mine closure. Section 41 of the MPRDA specifically refers to the financial provision of rehabilitation of exploration or mining sites and requires that a provision be maintained until the minister has issued a closure certificate in terms of Section 43 of the MPRDA (Republic of South Africa 2002). Regulations in this regard cover the quantum for the above-mentioned provision
(Swart 2003). The methods of above-mentioned provision include trust funds, written guarantees, financial deposits and other methods (Dixon 2003). From the above, it is clear that legislation governing mine closures in South Africa influences the monetary balance of the mine closure obligations and the related disclosures, to be found in the corporate annual reports and corporate social responsibility reports, also called sustainability reports.

Only companies with a primary listing on the JSE would be bound by its listing requirements, which include complying with the King Code (JSE 2015). The King Code stipulates that sustainability includes environmental considerations, but stops short of providing a detailed framework for environmental, social and governance disclosures (Carels, Maroun \& Padia 2013). The most widely used codes for best disclosure practice by mining companies in South Africa include the GRI's G3 (currently G4) reporting guidelines, specifically the mining sector supplement and carbon disclosure project (Carels et al. 2013). The GRI focusses on the aspects of economic, social and environmental impact, as a reporting framework on corporate sustainability (Cronjé \& Buys 2015). The JSE listing requirements also require mining companies to comply with the South African Code for Reporting of Exploration Results, Mineral Resources and Mineral Reserves (JSE 2015). The International Integrated Reporting Framework does not prescribe specific key performance indicators relating to mine closure obligations, but is principles-based and requires disclosure of matters that are material to value creation (IIRC 2013). The JSE listing requirements therefore also influence the level of mine closure obligation disclosure.

\section{Theory}

Financial reporting is aimed at all users of information about the entity's business, operations and the management's stewardship of an entity's resources (Cronjé \& Moolman 2013). Literature dealing with why companies disclose social and environmental information generally predicts an association between profitability and corporate social responsible reporting based on three theoretical frameworks including stakeholders, legitimacy and proprietary costs theories.

Stakeholder theory suggests that companies try to manage their relationships with different stakeholders to gain competitive advantage, therefore lead to better financial performance (Khlif et al. 2015). In response to pressures from various stakeholders such as governments, environmental groups, employees and the public, companies increase corporate social responsible reporting. Legitimacy theory suggests that companies provide additional corporate social responsible reporting in response to social pressure and to secure credibility in the society they operate (Maroun 2015). Proprietary costs theory suggests that companies with low economic performance are not able to bear the additional costs of additional non-financial disclosure and would rather place more emphasis on activities that influences directly the earnings of the company (Cormier \& Magnan 2013). 
Institutional theory suggests companies implement rules and structure, including corporate social responsible reporting patterns to legitimise themselves (de Villiers \& Alexander 2014). This leads to disclosure of corporate social responsible reporting in a uniform way that reveals little about a company's social responsible commitment.

This study does not attempt to support or refute any of the theoretical stances discussed above. Theory tells us that information reported in annual reports is not only useful to capital providers but also useful to other users as the users of annual reports are heterogeneous (Cronjé 2010). The extent of the information included in annual reports is influenced more by a need of compliance with legal and financial reporting standards and becomes a disclosure checklist exercise. Atkins and Maroun (2015) found in their study of perspectives from South African institutional investor of integrated reporting in South Africa that the most important need is to define and engage with primary and secondary stakeholders to identify relevant information needs and to avoid generic disclosures. This study attempts to point out that environmental disclosures reveal little information relating to the provisions for decommissioning and rehabilitation, even though it is in the South African public's interest to ensure the 'polluter pays' principle is followed as specified in the MPRDA.

\section{Research method}

As South Africa is the largest producer of platinum in the world (Platinum Today 2015), it was decided to conduct a census of the companies listed under the platinum and precious metal sub-sector under the mining sector on the JSE. There are 11 companies listed under this sub-sector. One of the companies has a suspended status, and therefore, the population of this study is the remaining 10 companies. Anglo American Platinum Ltd (Amplats) is the world's leading primary producer of platinum and accounts for about $40 \%$ of the world's newly mined platinum, whereas Impala Platinum Holdings Limited (Implats) produces approximately $22 \%$ of the world's supply of primary platinum. Both are listed under the platinum and precious metal sub-sector on the JSE (Amplats 2015; Implats 2015).

The study specifically concentrates on the level of mine closure obligations disclosure. The 2014 annual financial statements, integrated annual reports and sustainability reports or websites of companies listed under the platinum and precious metal sub-sector under the mining sector on the JSE were scrutinised. Four of the ten companies listed under the platinum and precious metal sub-sector under the mining sector on the JSE have primary listings elsewhere and did not produce integrated reports.

A census of the annual financial statements, integrated annual reports and sustainability reports or websites was conducted with the aid of a disclosure framework. The disclosure framework was based on the recommendations concerning the disclosure of mine closure provisions suggested by Deloitte (2007) and aspects relating to mine closure mentioned in the mining and metals sector disclosure of the G4 Sustainability Reporting Guidelines (GRI 2013). Content analysis is regularly used to research disclosures related to corporate social responsibility, and environmental and intellectual capital in annual reports (Samkin, Schneider \& Tappin 2014). The aim of the content analysis is not to determine the quantity of mine closure obligations disclosure by counting words, headings and figures (Carels et al. 2013). Instead, the aim is to determine the level of compliance of mine closure obligations disclosure to the recommended disclosure framework. The recommended disclosure framework concerning the disclosure of mine closure obligations is produced in Table 1 .

\section{Ethical consideration}

Secondary data that is publicly available are used. The College of Accounting Sciences Research Ethics Review Committee approved the research.

TABLE 1: Recommended disclosure framework in respect of mine closure obligations.

\begin{tabular}{|c|c|}
\hline Principle & Description terms to include \\
\hline 1. Clear description of the scope of liabilities covered by the provision & $\begin{array}{l}\text { 1.1 Reference to the compliance with current legislation that specifically establishes the } \\
\text { mine closure liabilities } \\
\text { 1.2 A reconciliation showing total land disturbed and not rehabilitated with annual } \\
\text { changes showing amount of land newly disturbed and amount of land newly rehabilitated } \\
\text { to the agreed end use } \\
\text { 1.3 Summary of sites and areas that are included within the provision } \\
\text { 1.4 The plan relating to the decommissioning and rehabilitation works described }\end{array}$ \\
\hline $\begin{array}{l}\text { 2. Outline description of the process and parties involved in defining the scope of work } \\
\text { and estimated costs of decommissioning works }\end{array}$ & $\begin{array}{l}2.1 \text { Key parameters and assumptions used in defining the scope of work and estimated } \\
\text { costs } \\
2.2 \text { Involvement of management or third parties in estimating the scope of work and } \\
\text { costs } \\
2.3 \text { Confirmation of the independence of any third party involved in the estimation } \\
\text { process }\end{array}$ \\
\hline 3. Provision of supporting information to be provided in a standardised form & $\begin{array}{l}\text { 3.1 A reconciliation of the provision in terms of IAS } 37 \text { Provisions, Contingent Liabilities } \\
\text { and Contingent Assets } \\
\text { 3.2 Key values on which the carrying amount of the closure provision is based: } \\
\text { 3.2.1 Total undiscounted estimated cash flow } \\
\text { 3.2.2 Expected timing of eventual cash payment } \\
\text { 3.2.3 Credit-adjusted risk-free rate at which the estimated cash flows have been } \\
\text { discounted } \\
\text { 3.3 The accounting treatment adopted for the elements of the decommissioning and } \\
\text { rehabilitation costs with respect to the booking of the provision (increasing the related } \\
\text { assets) }\end{array}$ \\
\hline
\end{tabular}

Source: Adapted from: Deloitte, 2007, A deeper level of detail. Improving the reporting of mine closure liabilities, Deloitte, London, pp. 1-14; Global Reporting Initiative (GRI), 2013, G4 Sector disclosures mining and metals, viewed 27 July 2015, from https://www.globalreporting.org/standards/sector-guidance/sectorguidanceG4/Pages/default.aspx 


\section{Results and comments}

The research findings are summarised in two sections. The first subsection summarises the findings of the six companies with primary listings under the platinum and precious metal sub-sector on the JSE, and the second subsection summarises the findings of the four companies listed under the platinum and precious metal sub-sector on the JSE, but with primary listings elsewhere. Tables 2 to 7 indicate the number of companies that disclosed the recommended disclosure framework information.

\section{Disclosure of recommended disclosure framework information in respect of mine closure obligations by companies with primary listings under the platinum and precious metal sub-sector on the JSE}

The findings relating to the three principles of the recommended disclosure framework are summarised below.

All of the companies made reference to compliance with current legislation that establishes the mine closure liability in their annual financial statements and integrated reports, and to a lesser extent in their sustainable development reports. Although none of the companies provided a reconciliation showing total land disturbed and not rehabilitated with annual changes, three (50\%) of the companies disclosed some information regarding either total land disturbed or disturbed land rehabilitated in either the sustainable development report or the integrated annual report. Three (50\%) of the companies disclosed the sites and areas that are included in the mine closure obligations in their sustainability report, whereas three $(50 \%)$ of the companies described the type of decommissioning and rehabilitation works in their integrated annual report. The findings in Table 2 show that the information disclosed by the six companies with primary listings under the platinum and precious metal sub-sector on the JSE is not consistent and transparent enough for interested parties to be better informed as to the scope of the liabilities included in the mine closure obligation.

The findings in Table 3 show that the details of the parameters and the assumptions used in determining the scope and the costs involved in rehabilitation or decommissioning is poorly described, whereas three (50\%) of the companies do describe the parties involved in defining the scope and the estimated costs of rehabilitation or decommissioning in either their

TABLE 2: Principle 1: Clear description of the scope of liabilities covered by the provision $(n=6)$.

\begin{tabular}{|c|c|c|c|}
\hline $\begin{array}{l}\text { Principle 1: Clear description of the scope of liabilities covered by the } \\
\text { provision }\end{array}$ & Annual financial statements & Integrated annual report & $\begin{array}{l}\text { Sustainable development report or } \\
\text { website }\end{array}$ \\
\hline $\begin{array}{l}1.1 \text { Is reference made to the compliance with current legislation that } \\
\text { establishes the mine closure liability? }\end{array}$ & 6 & 6 & 3 \\
\hline $\begin{array}{l}1.2 \text { Is a reconciliation showing total land disturbed and not rehabilitated } \\
\text { with annual changes (newly disturbed and rehabilitated land) provided? }\end{array}$ & 0 & 0 & 0 \\
\hline $\begin{array}{l}1.3 \text { Is a summary of sites and areas that are included in the provision } \\
\text { provided? }\end{array}$ & 1 & 1 & 3 \\
\hline 1.4 Is the plan of the decommissioning and rehabilitation works described? & 2 & 3 & 2 \\
\hline
\end{tabular}

Source: Adapted from: Deloitte, 2007, A deeper level of detail. Improving the reporting of mine closure liabilities, Deloitte, London, pp. 1-14; Global Reporting Initiative (GRI), 2013, G4 Sector disclosures mining and metals, viewed 27 July 2015, from https://www.globalreporting.org/standards/sector-guidance/sectorguidanceG4/Pages/default.aspx

TABLE 3: Principle 2: Outline description of the process and parties involved in defining the scope of work and estimated costs of decommissioning works $(n=6)$.

Principle 2: Outline description of the process and parties involved in defining the scope of work Annual financial Integrated annual Sustainable development and estimated costs of decommissioning works report or website

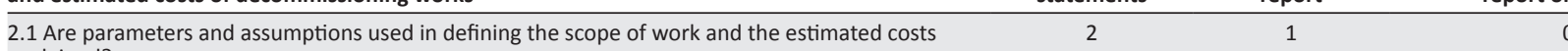
explained?

2.2 Is the involvement of management or third parties in estimating the scope of work and estimated costs mentioned?

2.3 Is confirmation of the independence of third parties involved in the estimation process included 3
3

3
3

0

1

0

Source: Adapted from: Deloitte, 2007, A deeper level of detail. Improving the reporting of mine closure liabilities, Deloitte, London, pp. 1-14; Global Reporting Initiative (GRI), 2013, G4 Sector disclosures mining and metals, viewed 27 July 2015, from https://www.globalreporting.org/standards/sector-guidance/sectorguidanceG4/Pages/default.aspx

TABLE 4: Principle 3: Provision of supporting information to be provided in a standardised form $(n=6)$.

Principle 3: Provision of supporting information to be Annual financial statements Integrated annual report Sustainable development report or website
provided in a standardised form

3.1 Is reconciliation in terms of IAS 37 Provisions, Contingent Liabilities and Contingent Assets provided?

3.2 Are key values on which the mine closure obligation provision is based disclosed? Including

3.2.1 the total undiscounted estimated cash flow

5

3.2.2 expected timing of eventual cash payments

5

3.2.3 the credit-adjusted risk-free rate at which the estimated cash flows have been discounted

3.3 Is the accounting treatment adopted for the elements of the decommissioning and rehabilitation costs with respect to the booking of the provision provided?

Source: Adapted from: Deloitte, 2007, A deeper level of detail. Improving the reporting of mine closure liabilities, Deloitte, London, pp. 1-14; Global Reporting Initiative (GRI), 2013, G4 Sector disclosures mining and metals, viewed 27 July 2015, from https://www.globalreporting.org/standards/sector-guidance/sectorguidanceG4/Pages/default.aspx 
annual financial statements or integrated annual reports. A range of variables impact the judgements used in determining the mine closure obligation. The findings in Table 3 show that the description of the process and parties involved in defining the scope and estimated costs of rehabilitation or decommissioning disclosed by the six companies with primary listings under the platinum and precious metal sub-sector on the JSE is not sufficient for interested parties to understand the key assumptions, parameters or reliability of the assessment and calculation of the mine closure obligation.

One of the companies with a primary listing under the platinum and precious metal sub-sector on the JSE was only doing exploration drilling, and rehabilitation was done on an ongoing basis at the drilling sites; therefore, the company did not disclose a mine closure obligation. The findings in Table 4 show that all the companies with a mine closure obligation with a primary listing under the platinum and precious metal sub-sector on the JSE disclosed the supporting information in their annual financial statements as recommended by the disclosure framework listed in Table 1. The same information was rarely disclosed elsewhere.

\section{Disclosure of recommended disclosure framework information in respect of mine closure obligations by companies listed under the platinum and precious metal sub-sector on the JSE, but with primary listings elsewhere $(N=4)$}

The findings relating to the three principles of the recommended disclosure framework are summarised below.

The majority $(75 \%)$ of the companies made reference in their sustainability development report or on their website to compliance with current legislation that establishes the mine closure liability. One of the companies disclosed a reconciliation of total land disturbed and not rehabilitated with annual changes in its sustainability development report, whereas none of the others disclosed any information relating to land disturbed or rehabilitated. Two (50\%) companies disclosed the sites and areas that are included in the mine closure obligations and described the type of decommissioning and rehabilitation works in their annual financial statements. The findings in Table 5 show that the information disclosed by the four companies listed under the platinum and precious metal subsector on the JSE, but with primary listings elsewhere, is inconsistent and do not provide a clear description of the scope of liabilities covered by the mine closure obligation.

The findings in Table 6 show that the description of the process and parties involved in defining the scope and estimated costs of rehabilitation or decommissioning disclosed by the four companies listed under the platinum and precious metal sub-sector on the JSE, but with primary listings elsewhere, is not sufficient for interested parties to understand the process and parties involved in defining the scope of work and estimated costs involved in determining the mine closure obligation.
The findings in Table 7 show that the companies listed under the platinum and precious metal sub-sector on the JSE, but with primary listings elsewhere, disclosed the supporting information relating to the mine closure obligation in the annual financial statements. Only two (50\%) of the companies disclosed total undiscounted estimated cash flow, expected timing of eventual cash payments and the credit-adjusted risk-free rate at which the estimated cash flows have been discounted in their annual financial statements.

\section{Conclusions and recommendations}

With the introduction of the International Integrated Reporting Framework and the GRI guidelines, many mining companies have taken steps to be more transparent in the disclosure of material environmental factors. However, crucial areas remain where mining companies fail to be transparent. There is evidence that the type of information in respect of mine closure obligations disclosed by companies listed under the platinum and precious metal sub-sector on the JSE is varied and not sufficient to allow effective scrutiny by interested parties.

The majority of companies listed under the platinum and precious metal sub-sector on the JSE lacks disclosure relating to the scope of liabilities, description of the process and parties involved in defining the scope of work and estimated costs of the mine closure obligations as recommended by the disclosure framework. The information recommended by the disclosure framework is disclosed in various reports. Interested parties have to scrutinise various reports to find all of the information disclosed by a company relating to its mine closure obligations.

Mine closure obligations are economically significant, and it is of public interest that mine closure obligations are regulated. The assumptions used to determine mine closure obligations are specialised and multi-disciplinary. The accuracy and reliability of mine closure obligations will improve dramatically through greater transparency and access to information. It is recommended that the JSE listings requirements for mining companies require a competent person's report to provide disclosure on assumptions, key values and processes applied to determine the mine closure obligations. This will allow greater transparency and access to information for effective public scrutiny. Furthermore, for holders of exploration or mining rights other than companies listed on the JSE, it is recommended that the Department of Mineral Resources (DMR) adopt a mine closure obligations disclosure framework to be submitted on an annual basis to the DMR for independent assessment by experts. These disclosures should be made available to ensure effective public scrutiny.

This study has some limitations. The size and nature of our sample precludes generalising results, but the intention of 
TABLE 5: Principle 1: Clear description of the scope of liabilities covered by the provision $(n=4)$.

Principle 1: Clear description of the scope of liabilities Annual financial statements

Sustainable development report or website

1.1 Is reference made to the compliance with current

legislation that establishes the mine closure liability?

1.2 Is a reconciliation showing total land disturbed and not

rehabilitated with annual changes (newly disturbed and

rehabilitated land) provided?

1.3 Is a summary of sites and areas that are included in the provision provided?

1.4 Is the plan of the decommissioning and rehabilitation works described?

2

0
0

Source: Adapted from: Deloitte, 2007, A deeper level of detail. Improving the reporting of mine closure liabilities, Deloitte, London, pp. 1-14; Global Reporting Initiative (GRI), 2013, G4 Sector disclosures mining and metals, viewed 27 July 2015, from https://www.globalreporting.org/standards/sector-guidance/sectorguidanceG4/Pages/default.aspx

TABLE 6: Principle 2: Outline description of the process and parties involved in defining the scope of work and estimated costs of decommissioning works $(n=4)$.

Principle 2: Outline description of the process and parties involved in defining the scope of Annual financial statements Sustainable development report or website work and estimated costs of decommissioning works

2.1 Are parameters and assumptions used in defining the scope of work and the estimated costs explained?

2.2 Is the involvement of management or third parties in estimating the scope of work and estimated costs mentioned?

2.3 Is confirmation of the independence of third parties involved in the estimation process included in the description?

Source: Adapted from: Deloitte, 2007, A deeper level of detail. Improving the reporting of mine closure liabilities, Deloitte, London, pp. disclosures mining and metals, viewed 27 July 2015, from https://www.globalreporting.org/standards/sector-guidance/sectorguidanceG4/Pages/default.aspx

TABLE 7: Principle 3: Provision of supporting information to be provided in a standardised form $(n=4)$.

Principle 3: Provision of supporting information to be provided in a Annual financial statements

3.1 Is reconciliation in terms of IAS 37 Provisions, Contingent Liabilities and Contingent Assets provided?

3.2 Are key values on which the mine closure obligation provision is based disclosed? Including

3.2.1 the total undiscounted estimated cash flow

$4+0$

3.2.2 expected timing of eventual cash payments

2

2

3.2 .3 the credit-adjusted risk-free rate at which the estimated cash flows have been discounted

3.3 Is the accounting treatment adopted for the elements of the decommissioning and rehabilitation costs with respect to the booking of the provision provided?

Source: Adapted from: Deloitte, 2007, A deeper level of detail. Improving the reporting of mine closure liabilities, Deloitte, London, pp. 1-14; Global Reporting Initiative (GRI), 2013, G4 Sector disclosures mining and metals, viewed 27 July 2015, from https://www.globalreporting.org/standards/sector-guidance/sectorguidanceG4/Pages/default.aspx

the study was to conduct a census of the platinum mines listed on the JSE to show that even with the introduction of the International Integrated Reporting Framework and the GRI guidelines, environmental disclosures reveal little information relating to the provisions for decommissioning and rehabilitation. The framework checklist is not able to entirely remove subjectivity in evaluating requirements which were measured. Future research could include defining and engaging stakeholders to identify relevant information needs relating to provisions for decommissioning and rehabilitation.

\section{Acknowledgements Competing interests}

The authors declare that they have no financial or personal relationships that may have inappropriately influenced them in writing this article.

\section{Authors' contributions}

Both authors were involved in the analysis of the reports of the companies. J.S. was involved in the writing of the article and C.J.C. reviewed, edited, commented and made recommendations.

\section{References}

Anglo American Platinum Ltd (Amplats), 2015, A global leader in platinum group metals, from resource to market, viewed 05 June 2015, from http://www. angloamerican.com/products/platinum

Atkins, J. \& Maroun, W., 2015, 'Integrated reporting in South Africa in 2012: Perspectives from South African institutional investors', Meditari Accountancy Research 23(2), 197-221. https://doi.org/10.1108/MEDAR-07-2014-0047

Auditor-General South Africa, 2009, Report of the Auditor-General to Parliament on a performance audit of the rehabilitation of abandoned mines at the Department of Minerals and Energy, Auditor-General South Africa, Pretoria, p. 5.

Carels, C., Maroun, W. \& Padia, N., 2013, 'Integrated reporting in the South African mining sector', Journal of Corporate Ownership \& Control 11(1), 957-971. https:// doi.org/10.22495/cocv11i1c11p6

Cormier, D. \& Magnan, M., 2003, 'Environmental reporting management: A continental European perspective', Journal of Accounting and Public Policy 22(1) 43-62. https://doi.org/10.1016/S0278-4254(02)00085-6

Cronjé, C.J., 2010, 'A more subtle set of information in corporate annual reports for disadvantaged stakeholders', South African Journal of Economic and Management Sciences 13(2), 222-235.

Cronjé, C.J. \& Buys, P., 2015, 'Perspectives on effective communication of corporate sustainability reporting', Corporate Ownership \& Control 12(4 conference issue), 819-825.

Cronjé, C.J. \& Moolman, S., 2013, 'Intellectual capital: Measurement, recognition and reporting', South African Journal of Economic and Management Sciences 16(1), 1-12.

De Villiers, C.J. \& Barnard, P., 2000, 'Environmental reporting in South Africa from 1994 to 1999: A research note', Meditari Accountancy Research 8(1), 15-23. https://doi.org/10.1108/10222529200000002

De Villiers, C. \& Alexander, D., 2014, 'The institutionalisation of corporate social responsibility reporting', British Accounting Review 46, 198-212. https://doi. org/10.1016/j.bar.2014.03.001

De Villiers, C., Low, M. \& Samkin, G., 2014, 'The institutionalisation of mining company sustainability disclosures', Journal of Cleaner Production 84, 51-58. https://doi. org/10.1016/j.jclepro.2014.01.089 
Deegan, C. \& Rankin, M., 1996, 'Do Australian companies report environmental news objectively? An analysis of environmental disclosures by firms prosecuted successfully by the Environmental Protection Authority', Accounting, Auditing and successfully by the Environmental Protection Authority', Accounting, Auditing and
Accountability Journal 9(2), 52-69. https://doi.org/10.1108/09513579610116358

Deloitte, 2007, A deeper level of detail. Improving the reporting of mine closure liabilities, Deloitte, London, pp. 1-14.

Dixon, C., 2003, 'Mine closure from legal perspective: Do the provisions of the new Mineral and Petroleum Resources Development Act and draft regulations make closure legally attainable?' The Journal of the South African Institute of Mining and Metallurgy 103(8), 483-488.

Dye, R.A., 1985, 'Disclosure of nonproprietary information', Journal of Accounting Research 23(1), 123-145. https://doi.org/10.2307/2490910

Ferguson, A. \& Walker, A., 2011, Restoration and rehabilitation provisions in the Australian materials and energy sectors; Estimation and valuation implications, viewed 09 June 2015, from https://www.business.unsw.edu.au/About-Site/ Schools-Site/Accounting-Site/Documents/A.\%20Ferguson\%20-\%20Restoration $\% 20$ and $\% 20$ Rehabilitation $\% 20$ Provisions.pdf

Global Reporting Initiative (GRI), 2013, G4 Sector disclosures mining and metals, viewed 27 July 2015, from https://www.globalreporting.org/standards/sectorguidance/sectorguidanceG4/Pages/default.aspx

Impala Platinum Holdings Limited (Implats), 2015, Implats fact sheet, viewed 1 February 2015, from http://www.implats.co.za/implats/downloads/2015/fact_ sheets/Implats_Factsheet_Jan_2015.pdf

International Accounting Standards Board (IASB), 2014, A guide through Internationa Financial Reporting Standards as issued at 1 July 2014, IFRS Foundation, London.

International Integrated Reporting Council (IIRC), 2013, The International $\langle I R\rangle$ framework, viewed 27 July 2015, from http://integratedreporting.org/wpcontent/uploads/2013/12/13-12-08-the-international-ir-framework-2-1.pdf

JSE Limited (JSE), 2015, JSE listing requirements, viewed 09 June 2015, from https:// www.jse.co.za/content/JSEEducationltems/Service\%20lssue\%2017.pdf

Khlif, H., Hussainey, K. \& Achek, I., 2015, 'The effect of national culture on the association between profitability and corporate social and environmental disclosure: A meta-analysis', Meditari Accountancy Research 23(3), 296-321. https://doi.org/10.1108/MEDAR-12-2014-0064

Magness, V., 2006, 'Strategic posture, financial performance and environmental disclosure: An empirical test of legitimacy theory', Accounting, Auditing \& AccountabilityJournal19(4),340-363.https://doi.org/10.1108/09513570610679128

Maroun, W., 2015, 'Culture, profitability, non-financial reporting and a meta-analysis: Comments and observations', Meditari Accountancy Research 23(3), 322-330. https://doi.org/10.1108/MEDAR-04-2015-0020
Neu, D., Warsame, H. \& Pedwell, K., 1998, 'Managing public impressions: Environmental disclosure in annual reports' Accounting Organizations and Society 23(3), 265-282. https://doi.org/10.1016/S0361-3682(97)00008-1

Platinum Today, 2015, About PGM production, viewed 09 June 2015, from http:// www.platinum.matthey.com/about-pgm/production

Republic of South Africa, 2002, Mineral and Petroleum Resources Development Act 28 of 2002, Government Printer, Pretoria.

Rio Tinto, 2012, Sustainable development 2012, viewed 09 June 2015, from http:// www.riotinto.com/sustainabledevelopment2012/governance/closure.htm

Roberts, R.W., 1992, 'Determinants of corporate social responsibility disclosure: An application of stakeholder theory', Accounting, Organizations and Society 17(6) 595-612. https://doi.org/10.1016/0361-3682(92)90015-K

Samkin, G., Schneider, A. \& Tappin, D., 2014, ,Developing a reporting and evaluation framework for biodiversity', Accounting, Auditing \& Accountability Journal 27(3), 527-561. https://doi.org/10.1108/AAAJ-10-2013-1496

Summerhays, K. \& de Villiers, C., 2012, 'Oil company annual report disclosure responses to the 2010 Gulf of Mexico oil spill', Journal of the Asia-Pacific Centre for Environmental Accountability 18(2), 103-130.

Swart, E., 2003, 'The South African legislative framework for mine closure', The Journal of the South African Institute of Mining and Metallurgy 103(8), 489-492.

Tilt, C.A. \& Symes, CF., 1999, 'Environmental disclosure by Australian mining companies: Environmental conscience or commercial reality?' Accounting Forum 23(2), 137-154. https://doi.org/10.1111/1467-6303.00008

Van Eeden, E.S., Liefferink, M. \& Durand, J.F., 2009, 'Legal issues concerning mine closure and social responsibility on the West Rand', The Journal for Transdisciplinary Research in Southern Africa 5(1), 51-57.

Verrecchia, R., 1983, 'Discretionary disclosure', Journal of Accounting and Economics 5(1983), 179-194. https://doi.org/10.1016/0165-4101(83)90011-3

World Wide Fund for Nature (WWF), 2012, Financial provisions for rehabilitation and closure in South African mining: Discussion document on challenges and recommended improvements (Summary), WWF-SA, Cape Town, pp. 1-94.

Yoo, T. \& Nam, G., 2015, 'An expanded accounting framework for sustainable growth: Focus on the relationship between a focal firm and its stakeholders', South African Journal of Economic and Management Sciences 18(3), pp. 366-379. https://doi. org/10.17159/2222-3436/2015/v18n3a6

Zeng S.X Xu, X.D., Yin H.T \& Tam, C.M, 2011, 'Factors that drive Chinese listed companies in voluntary disclosure of environmental information', Journal of Business Ethics 109(3), 309-321. https://doi.org/10.1007/s10551-011-1129-x 